\title{
QUALITY MANAGEMENT OF ISLAMIC EDUCATIONAL INSTITUTIONS SERVICE (STUDY OF CUSTOMER SATISFACTION ANALYSIS IN MADRASAH IBTIDAIYAH AL-HUSNA CILEDUG TANGERANG CITY)
}

\author{
Imam Mashud'*, Agus Suradika², Gofur Ahmad ${ }^{3}$ \\ 'Scholar of Doctor Program, Muhammadiyah University of Jakarta, Indonesia \\ ${ }^{2}$ Profesor of pedagogic, Muhammadiyah University of Jakarta, Indonesia \\ ${ }^{3}$ Profesor of Economic Management, Muhammadiyah University of Jakarta, Indonesia \\ *imam.mashud21@gmail.com
}

\begin{tabular}{|c|c|}
\hline Article Info & ABSTRACT \\
\hline $\begin{array}{l}\text { Article history } \\
\text { Received: October 30, } 2020 \\
\text { Revised: November 23, } 2020 \\
\text { Accepted: December 22, } 2020 \\
\end{array}$ & $\begin{array}{l}\text { Management is a staple component that cannot separate } \\
\text { from Islamic educational institutions. Without management, } \\
\text { the purpose of the institution cannot realize optimally, } \\
\text { effectively, and efficiently. Problems in educational institutions }\end{array}$ \\
\hline $\begin{array}{l}\text { Keywords: } \\
\text { Customer satisfaction; } \\
\text { Madrasah; } \\
\text { Quality Management service; } \\
\text { Islamic Education. }\end{array}$ & $\begin{array}{l}\text { about planning, organizing, implementing, and evaluating } \\
\text { the quality management of Islamic education services. This } \\
\text { research method uses a quantitative approach, in the process } \\
\text { of data collection is carried out in four types of data collection } \\
\text { techniques, namely observation, interview, documentation, } \\
\text { and survey. The results of the calculation of customer } \\
\text { satisfaction of Islamic education in order to get a satisfaction } \\
\text { index of } 71 \% \text { of the services provided by Madrasah lbtidaiyah } \\
\text { Al-Husna Ciledug, so that it must make improvements in the } \\
\text { quality of service. This is because in the calculation of the } \\
\text { overall Servqual gap value still shows a negative value of -0.7 } \\
\text { to the service provided by Madrasah Ibtidaiyah Al-Husna } \\
\text { Ciledug. Improvement of service quality carried out on } \\
\text { attributes that have the highest gap. The purpose of improving } \\
\text { the quality of service is to give parents satisfaction as } \\
\text { customers of Islamic education can be accommodated. }\end{array}$ \\
\hline
\end{tabular}

\section{INTRODUCTION}

In family life, organizing, community, and nationalization, management is the first effort to achieve a common goal. Education is an essential part of human life and should receive significant attention in management. For a nation or country, an adequate level of education is no exception to Islam's development. In Islam, education must be managed and implemented to the fullest. The implementation of Islamic education is a means to improve the quality of human life in moral, material and spiritual situations left behind.

In education, quality can see as a useful tool in fighting for educational institutions' existence. Quality can help in winning the competition of educational institutions that are increasingly mushrooming. However, with the same quality, it is no longer the main guarantee 
in competing. To win the competition, educational institutions must look at the dimensions of quality of educational services slickly. Service quality satisfaction and satisfied consumers of education become very important for educational institutions. Similarly, educational institutions need to pay attention to some things that need to address, such as strengthening the quality of services and their impact on educational customers' satisfaction and their behaviour after using educational services provided by educational institutions.

Idrus (2012), one of the problems in education is the low quality of education. The research results mentioned that uneven education services cause the low quality of education (Idrus, 2012). Many factors determine the low quality of education, one of which is providing educational services that are still far from expected. On the one hand, the provision of educational services is not the most appropriate method, on the other hand, the development of science and technology and the social needs of people who become educational customers are also increasing. Usually, with the support of various unique products, physical services are provided in administrative services and training services. The main product of this problem is usually a particular service.

In general, total service quality defines a service as a job done by someone on others' behalf. In their research, Pramana and Rastini (2016) explained that the quality of service positively impacts increasing customer confidence. At the same time, Prasetya and Muhammad (2015), in their research, showed that quality and sustainable service quality could improve consumer enjoyment and ultimately bring benefits. However, it is not easy to understand how to assess the quality that consumers receive due to the quality of service produced in the factory production process, which delivered to the consumer and the quality of the materials. Most of the service delivery process allocated through communication between customers, and there is personal communication with the service provider.

The essence of high-quality service is to strive to provide the best customer service by the interests of customers or users, to provide the most satisfaction. If we can demonstrate excellent and coordinated skills, attitudes, appearances, attention, actions and responsibilities, we can strive to provide the best service. In the era of globalization, quality is considered one of the tools to gain a competitive advantage. Because quality is one of the main factors that determine consumer products and services, according to Crosby (1979), quality is considered a requirement of meeting or conformance to requirements. These requirements are the requirements of consumers, not companies.

The emergence of Madrasah (Islamic education) considered a vital sign of the positive development of Muslim cultural achievement because education is so sustainable with Islamic phenomena that reflect the perfection of science, intellectuals, and cultural literacy. Therefore, pride in Madrasah arises because madrasah institution has the characteristic "trademark" in the eyes of the community. However, until now, the existence of madrassas in Indonesia is very different from Islam's resounding achievements in the past.

IJEMI Vol.2, No.1, January 2021, pp. 55 67 
Madrasah's main problem is usually the subject of intergroup discussion, especially in terms of quality, especially in private Madrasah. On the other hand, as mentioned above, the existence of the three ministers' policies of the joint decree (SKB), the SKB caused controversy about alternative dilemmas. First, the quality of religious education must be maintained, second, required to be able to conduct a quality and quality education similar to that of a public school.

According to data and information obtained by researchers, Madrasah Ibtidaiyah AlHusna Ciledug Tangerang city has always been committed to maximizing educational services by improving services from economy to business class. Madrasah Ibtidaiyah Al-Husna Ciledug Business Class Tangerang city refers to the business concept and expands the service from half-day learning activities to full-time, full AC classes, as well as using information technology in each class, catering healthy food as well as matching students' interest in extracurricular activities. In teaching and learning activities several supporting activities depend on the talents and interests of Madrasah Ibtidaiyyah Al-Husna Ciledug Tangerang City, such as simple research, science surgery, tourism, mass media subscriptions, days, English day, Arabic day and various extracurricular activities.

This research conducted to find out how educational services' performance can meet the interests, desires and needs of students. It needs to be doing to get correct and valid information about the inequality of education services as demonstrated by Madrasah ibtidaiyah Al-Husna Ciledug in Tangerang. The information can use as input for pesantren managers to improve quality based on the understanding of direct users of madrasah education services, thus making madrasah Ibtidaiyyah Al-Husna Ciledug Tangerang city as an educational institution that can consider because it can be said to be very good and to meet the demand from internal customers and external customers.

\section{LITERATURE REVIEW}

Management is the organization's primary power to implement and manage human and material resources. In any organization, management is a critical factor in achieving goals and achieving success. Stoner (2005) points out that management is a method of planning, organizing, and using institutional resources to achieve Kritiner (1989) states that management is an activity that passes others to achieve goals in a changing environment. Koontz and Weihrich (2008) say that management is the process of designing and determining an environment where one person can work together as a team. The team hopes that efficiency becomes an important goal. Appley (2000) states that management is the only way to achieve goals through the efforts of others. Simultaneously, according to Follet (2018) stated that management is a talent, as it requires special skills to work through others. From the understanding of these scientists, management refers to the knowledge and skills that govern 
the process of maximizing human resources and other resources practically to achieve the specified goals.

Service is any action or activity provided by another party, in principle irrelevant and has no ownership. Production can be connected or not physically related. Tjiptono (2005) explains that the Total Quality Service is a management system that uses all company components, which uses qualitative and quantitative methods to improve all company processes. The goal is to meet customers' needs, desires, or expectations and can even exceed customer expectations. Stamatis (1996) stated that an integrated strategy recommendation and management system for developing a total quality service draft, which includes all management elements and employees who use qualitative and quantitative methods to improve the service process to meet the needs and expectations of consumers. This difference in perception or impression and expectation or expectation is what underlies the concept of gap (perception-expectation gap) which used as the principle of service quality comparison (SERVQUAL), namely the quality of service measured in five forms, namely: 1) Tangible, 2) Reliability, 3) Responsiveness, 4) Assurance, and 5) Empathy.

\section{METHOD}

This research conducted at Madrasah Ibtidaiyah Al-Husna located in Ciledug Tangerang City, which became the object in this study is the guardian of students who use Islamic education services. This research is a quantitative method. According to Sugiyono (2016) called quantitative method because of the research data in the form of figures and analysis in statistics. The quantitative approach uses to achieve data on the satisfaction of parents' education services as education customers through students who are leaving it to Madrasah Ibtidaiyah Al-Husna Ciledug Tangerang City.

After the data obtained, the next step is to quantitative analysis carried out with descriptive techniques by processing one variable's data. This study's population are all parents who become customers of Islamic education in Madrasah Ibtidaiyah Al-Husna Ciledug in 2020, which numbered 788 people. In determining the number of Samples taken used the formula, Issac and Michael, through a table with a disability rate of $5 \%$, after calculating the number of samples used as many as 245 parents. The sample selected by accidental sampling method. The data analysis is a descriptive qualitative Service Quality. Analysis data tool used by using a Likert scale to evaluate the quality of service to be broken in service quality attributes includes actual dimensions, empathy, assurance, responsiveness and reliability. To find out the level of satisfaction of parents as educational customers qualified in the following table 1. 
Table 1. Scala Likert Analysis Questionnaire

\begin{tabular}{lll}
\hline No & Deviation value & Criteria \\
\hline 1 & $81-100$ & Very good \\
2 & $70-80$ & Good \\
3 & $60-69$ & enough \\
4 & $<60$ & Not good \\
\hline
\end{tabular}

\section{RESULT}

To find out the level of performance of Islamic education services in Madrasahas expected or not, researchers conducted a service analysis using Servqual approach as follows:

\subsection{Tangibles Dimension}

Dimensions of physical evidence or tangibles can be seen and felt such as building facilities or front office, comfort, neatness of the room, cleanliness, completeness of communication and the appearance of educators and educational personnel. In this physical evidence conference, the student's guardian as a customer of Islamic education uses his sense of vision and feelings in assessing the quality of service provided by madrasah. The results of the calculation of questionnaires on the dimensions of physical evidence (tangibles) filled by the parents of as many as 245 people can see from the table 2 .

Table 2. Tangible Dimension

\begin{tabular}{|c|c|c|c|c|}
\hline \multirow[t]{2}{*}{ No } & \multirow[t]{2}{*}{ Attribute } & \multicolumn{2}{|c|}{ Average } & \multirow[t]{2}{*}{ GAP } \\
\hline & & Fact & Hope & \\
\hline 1 & Strategic madrasah building location. & 3.71 & 4.64 & -0.93 \\
\hline 2 & $\begin{array}{l}\text { Building for representative, safe, and convenient learning } \\
\text { activities. }\end{array}$ & 3.72 & 4.56 & -0.84 \\
\hline 3 & Comfortable classroom. & 3.81 & 4.66 & -0.85 \\
\hline 4 & $\begin{array}{l}\text { The library facilities are quite complete, clean, and } \\
\text { comfortable. }\end{array}$ & 3.13 & 4.55 & -1.42 \\
\hline 5 & $\begin{array}{l}\text { Neatness in the appearance of educators and educational } \\
\text { personnel. }\end{array}$ & 3.82 & 4.54 & -0.72 \\
\hline 6 & $\begin{array}{l}\text { Supporting facilities (parking, clean bathroom, and clean } \\
\text { canteen). }\end{array}$ & 3.24 & 4.74 & -1.50 \\
\hline 7 & Have a website or school information on the internet. & 3.48 & 4.43 & -0.95 \\
\hline 8 & The safe and clean school environment & 3.92 & 4.69 & -0.77 \\
\hline 9 & Table chairs are all nice and tidy & 3.79 & 4.78 & -0.99 \\
\hline \multicolumn{2}{|c|}{ Average amount } & 3.92 & 4.62 & -0.70 \\
\hline
\end{tabular}

Based on the results of Table 2 shows the results that the physical evidence (tangibles) available in Madrasah get the highest gap results in the 6th attribute with a gap value of -1.50 This attribute contains about supporting facilities such as parking for inadequate student transfers with the number of students, clean bathrooms and clean canteens. The lowest gap is at the 5 th attribute with a gap value of -0.72 . The 5 th attribute contains a statement about the neatness of educators and educational personnel. Overall attributes in the tangibles dimensions are in right criteria with an average value coverage of $70 \%$. 


\subsection{Reliability Dimension}

In the dimension of reliability, Madrasah's ability to provide accurate, precise and reliable services. The results of the calculation of questionnaires on the dimensions of reliability (reliability) filled by the parents of 245 people can see in the table 3 .

Table 3. Reliability Dimension

\begin{tabular}{|c|c|c|c|c|}
\hline \multirow[t]{2}{*}{ No } & \multirow{2}{*}{ Attribute } & \multicolumn{2}{|c|}{ Average } & \multirow[t]{2}{*}{ GAP } \\
\hline & & Fact & Hope & \\
\hline 1 & $\begin{array}{l}\text { the fast response and precise new student admission } \\
\text { procedures. }\end{array}$ & 3.69 & 4.53 & -0.84 \\
\hline 2 & $\begin{array}{l}\text { Punctuality of time in the process of teaching and learning } \\
\text { activities. }\end{array}$ & 3.72 & 4.57 & -0.56 \\
\hline 3 & $\begin{array}{l}\text { Serious attention of educators and educators to the student with } \\
\text { problems. }\end{array}$ & 3.96 & 4.67 & -0.71 \\
\hline 4 & Speed in administrative services. & 3.79 & 4.40 & -0.61 \\
\hline 5 & Accuracy of teachers and staff in administration. & 3.66 & 4.55 & -0.89 \\
\hline 6 & $\begin{array}{l}\text { Implementation of extracurricular activities, development of } \\
\text { student interests and talents. }\end{array}$ & 3.75 & 4.54 & -0.79 \\
\hline 7 & $\begin{array}{l}\text { Graduate teachers and staff according to their educational } \\
\text { background. }\end{array}$ & 3.70 & 4.53 & -0.83 \\
\hline \multicolumn{2}{|c|}{ Average amount } & 3.79 & 4.54 & -0.75 \\
\hline
\end{tabular}

Table 3 shows that the dimensions of reliability (reliability) available in Madrasah ibtidaiyah Al-Husna Ciledug get the highest gap to result in the 5th attribute, which is the accuracy of teacher's staff completing administration with a gap value of -0.89 . The lowest gap is in the 2nd attribute, which is the accuracy of the use of time in teaching and learning activities with a gap value of -0.56 . Overall attributes in dimensions of reliability (reliability) are good with an average value coverage of $75 \%$.

\subsection{Responsive Dimension}

The responsive dimension is madrasah's ability as a service institution to help parents as customers provide instant service. This responsiveness is in the form of responsiveness from educators and educational personnel to help students and guardians deal with problems both academically and non-academically. The results of the calculation of questionnaires on responsive dimensions filled by the parents of 245 people can see in table 4.

Table 4. Responseveness Dimention

\begin{tabular}{|c|c|c|c|c|}
\hline \multirow{2}{*}{ No } & \multirow{2}{*}{ Attribute } & \multicolumn{2}{|c|}{ Average } & \multirow{2}{*}{ GAP } \\
\hline & & Fact & Hope & \\
\hline 1 & Responsive to students need in learning & 3.78 & 4.64 & -0.86 \\
\hline 2 & Awareness in assisting students quickly. & 3.80 & 4.40 & -0.56 \\
\hline 3 & Awareness help student's difficulties. & 3.88 & 4.60 & -0.72 \\
\hline 4 & Take the time to respond to students requests. & 3.76 & 4.41 & -0.43 \\
\hline 5 & The speed of administration in administration services. & 3.98 & 4.67 & -0.69 \\
\hline
\end{tabular}




\begin{tabular}{|c|c|c|c|c|}
\hline \multirow[t]{2}{*}{ No } & \multirow[t]{2}{*}{ Attribute } & \multicolumn{2}{|c|}{ Average } & \multirow[t]{2}{*}{ GAP } \\
\hline & & Fact & Hope & \\
\hline 6 & Accuracy of teachers in administrative. & 3.78 & 4.42 & -0.64 \\
\hline 7 & The friendly attitude of the teacher and staff. & 4.16 & 4.83 & -0.67 \\
\hline \multicolumn{2}{|c|}{ Average amount } & 3.87 & 4.56 & -0.69 \\
\hline
\end{tabular}

Table 4 shows the result that Madrasah's responsive dimensions get the highest gap results in the 1st attribute that is responsive to the needs of students in the learning process with a gap value of -0.86 . The lowest gap is in the 4 th attribute, which is to take the time to respond to a student's request with a gap value of -0.43 . Overall attributes in the responsive dimension are in the category enough with an average value of $69 \%$.

\subsection{Assurance Dimension}

In the dimension of assurance, is the ability of madrasah as a service institution to help the parents as customers provide fast and appropriate service. This guarantee is in ethics, knowledge, educator's skill, and educational personnel in providing services. The results of the questionnaire calculation on the dimensions of assurance (assurance) filled by the parents of 245 people can see in the following table 5.

Table 5. Assurance Dimension

\begin{tabular}{|c|c|c|c|c|}
\hline \multirow[t]{2}{*}{ No } & \multirow[t]{2}{*}{ Attribute } & \multicolumn{2}{|c|}{ Average value } & \multirow[t]{2}{*}{ GAP } \\
\hline & & Fact & Hope & \\
\hline 1 & $\begin{array}{l}\text { Teachers and staff competencies according to the field of } \\
\text { expertise and employment. }\end{array}$ & 3.85 & 4.64 & -0.79 \\
\hline 2 & $\begin{array}{l}\text { The result of the students learning progress report by the } \\
\text { teacher. }\end{array}$ & 3.99 & 4.53 & -0.54 \\
\hline 3 & Honesty and trustworthy in teachers and staff. & 3.93 & 4.61 & -0.70 \\
\hline 4 & Picket teachers and maintaining the orderly Madrasah. & 3.65 & 4.33 & -0.68 \\
\hline 5 & $\begin{array}{l}\text { New students in first grade get orientation introduction } \\
\text { madrasah environment. }\end{array}$ & 3.82 & 4.52 & -0.70 \\
\hline \multicolumn{2}{|c|}{ Average value } & 3.84 & 4.52 & -0.68 \\
\hline
\end{tabular}

Table 5 shows the result that Madrasah's responsive dimensions get the highest gap to result in the 1st attribute namely the competence of teachers and staff in the field of expertise and work with a gap value of -0.79 . The lowest gap is in the 2 nd attribute, which results from the teacher's learning progress report with a gap value of -0.54 . Overall, the responsive dimension attributes are in the category enough, with an average value of $68 \%$.

\subsection{Empathy Dimension}

In the dimension empathy, is the ability of madrasah as a service institution to help the parents as customers provide genuine service. This dimension of care is in the form of a sincere and personal attitude from educators and educational personnel in providing services. The 
results of the calculation of the questionnaire on the dimension of assurance (assurance) filled by the parents of 245 people can see in the table 6 .

Table 6. Empathy Dimension

\begin{tabular}{|c|c|c|c|c|}
\hline \multirow[t]{2}{*}{ No } & \multirow[t]{2}{*}{ Attribute } & \multicolumn{2}{|c|}{ Average } & \multirow[t]{2}{*}{ GAP } \\
\hline & & Fact & Hope & \\
\hline 1 & Ease of teachers and staff contact. & 3.81 & 4.60 & -0.79 \\
\hline 2 & $\begin{array}{l}\text { Ease of teachers and staff in responding to student } \\
\text { complaints. }\end{array}$ & 3.91 & 4.66 & -0.75 \\
\hline 3 & Teacher know the needs or desires of students. & 3.68 & 4.54 & -0.86 \\
\hline 4 & Fullday learning activities. & 3.54 & 4.12 & -0.58 \\
\hline 5 & Madrasah prioritizes the needs of the students. & 3.74 & 4.60 & -0.86 \\
\hline 6 & Madrasah provides individual services. & 3.70 & 4.19 & -0.49 \\
\hline 7 & There are guidance and counselling services for students. & 3.76 & 4.51 & -0.75 \\
\hline \multicolumn{2}{|c|}{ Average amount } & 3.73 & 4.46 & -0.73 \\
\hline
\end{tabular}

From the results of Table 6 shows the result that the dimension of empathy dimensions in Madrasah Ibtidaiyah Al-Husna Ciledug gets the highest gap results in the 3rd attribute which is the teacher knows the needs or desires of students with a gap value of -0.86 and the 5 th attribute that is about Madrasah knowing the needs of students with a gap of -0.86 . The lowest gap is in the 6th attribute that Madrasah provides individual services with a gap value of -0.49 . Overall attributes in responsive dimensions are in a good category with an average value coverage of $73 \%$.

Based on the above explanation, it can conclude that the entire attribute in each dimension has a negative value; this indicates that the service provided has not met the customer's expectations. The madrasah must improve the quality of service, especially at highvalue gaps from the results mentioned.

\section{DISCUSSION}

The quality management of Islamic education service in Madrasah was carrying out using SERVQUAL analysis covering five dimensions: tangibles, responsivity, reliability, assurance and empathy. The results of the analysis of five dimensions are as follows:

\subsection{Tangibles Dimension}

The quality of education services in the dimension of physical evidence (tangibles) is the institution's ability to show its existence to outside parties. Tangibles in the form of educational facilities and infrastructure, equipment used, and educational personnel serve parents as customers of Islamic education. Based on nine indicator data obtained weight of value of $70 \%$ with enough category. The results showed that the physical evidence (tangibles) carried out by the Madrasah was sufficient in providing Islamic education services to the parents as customers of Islamic education. 
In the dimensions of physical evidence (tangibles) the main indicators that must be improved and immediately improved by the Madrasah were the 6th indicator which is the supporting facilities in the form of parking facilities, clean bathrooms and a spacious and clean canteen with a gap value of -1.50 and the 4 th indicator which is a reasonably complete, clean, and comfortable library facility with a gap value of -1.42 .

With nearly 800 students and educators and educational personnel reaching 60 , especially during the student pick up time, the Parking Space Unit (PSU) for cars must be owned according to the standard of the Directorate General of Land Transportation as much as 20 PSU (1 PSU = $2.30 \mathrm{~m} \times 5.00 \mathrm{~m}$ ), while for motorcycles as much as $500 \mathrm{PSU}$ ( $1 \mathrm{PSU}=0.75 \mathrm{M} \times 2.00$ $\mathrm{m})$. the total parking lot required to facilitate the flow of student transfers is $1,000 \mathrm{~m}^{2}$. As for the parking lot owned by madrasah, there are $300 \mathrm{~m}^{2}$, so the madrassa needs to expand the parking lot of vehicles in order for the madrassa atmosphere to run orderly and smoothly. The bathroom is by the student comparison, which is 1: 20, optimize the madrassa cleaning assistant's performance in maintaining madrassa's cleanliness. For the canteen only controlled various kinds of snacks sold. Cooperation with PUSKESMAS tangible physical evidence then Sadhana (2009) argues that beauty and comfort in the environment, orderly service, comfortable waiting room with service support facilities, such as spacious parking lots, places of worship and clean toilets will increase the positive image for service implementers.

\subsection{Reliability Dimension}

The quality of education services in the dimension of reliability (reliability) is the ability of madrasah ibtidaiyah Al-Husna Ciledug in providing satisfactory and promising services. The service provided should be reliable, responsible, friendly and courteous. The dimension component of reliability (reliability) consisting of seven indicators, obtained an average weight value of 75 with the good category. The results showed that the madrasah's reliability was useful in providing Islamic education services to the parents as customers of Islamic education.

In the dimensions of reliability (reliability) available in Madrasah, the main indicator that must repair immediately is in the 5th attribute: the accuracy of teachers and staff completing administration with a gap value of -0.89 . The observations know that educators' performance should always be monitored by conducting regular coaching through academic supervision activities, administrative supervision, and clinical supervision.

The performance of education personnel or staff in conducting staff administration, student, curriculum, finance, and public relations processes has been well underway. The administration process on facilities and infrastructure and the process must be performance level and improved. Services considered reliable when an agreement reached accurately. This accuracy and precision increase consumer confidence in service providers. In general, the program should realize Madrasah based on the dimensions of reliability is quality learning activities, providing educators and competent educational personnel, conducive 
environment, implementation of extracurricular, extracurricular and co-curricular activities that fulfil the vision and mission of Madrasah.

\subsection{Responsivennes Dimension}

The quality of education services in the responsive dimension is madrasah Ibtidaiyah AlHusna Ciledug's ability to provide spontaneous services. Dimensions of responsiveness in institutions and educators and education personnel's ability to help educate customers when dealing with problems both academically, financially, and other administrations. The responsive dimension component consisting of seven indicators obtained an average weight value of 69 with enough categories. The results showed that the madrassa Ibtidaiyah Al-Husna Ciledug saw the responsiveness carried out as good enough in shaping the quality of Islamic education services to the parents as customers of Islamic education.

In the responsive dimensions available in Madrasah Ibtidaiyah Al-Husna Ciledug the main indicator that must be improved immediately is in the 1st attribute, which is about responsiveness to students' needs in learning activities with a gap value of -0.86 . Based on the observation, a teacher's results should be able to serve all students well and not choose love. Educators should be able to perform their duties professionally and responsibly. Gordon noted that professional educators are the one who can understand a wide range of problems, better understand, understand the broader and insightful science, fund more perfectly than people in general.

Responsive dimensions are part of the professionalism in the quality of service. This professionalism can provide service to customers. If a person works according to his skills or abilities, they referred to as a professional. If the work is doing by a person who has professional knowledge according to work, then the work can be completed quickly and appropriately. The trust given by consumers is mandatory. If the task wasted, it will affect the failure and destruction of the organization's services to customers.

Based on the analysis, the responsive dimension refers to employees' willingness to serve quickly and appropriately, the speed and accuracy of service in terms of professionalism. In terms of meaning, professional employees will be able to provide services appropriately and quickly. Therefore, consumer confidence as trust should not waste in providing professional services through employees who work in their respective fields and get the job done quickly and appropriately.

\subsection{Assurance Dimension}

The quality of education services in the assurance dimension is madrasah in knowledge or understanding of the services provided, courtesy and trust of service providers and concern 
for consumers. If the service provider shows respect, decency, and friendliness, this will increase consumers' positive awareness and the positive value of the service provider organization.

The assurance dimension component consisting of five indicators obtained an average weight value of 68 with enough categories. The results showed that assurance by Madrasah saw as good enough in establishing the quality of Islamic education services to the parents as customers of Islamic education. In the assurance dimension available in Madrasah Ibtidaiyah Al-Husna Ciledug the main indicator that must be immediately corrected is in the 1st attribute which is about the competence of teachers and staff in the field of expertise and its work with a gap value of -0.79 . Based on the results of observations obtained the results, namely Madrasah Ibtidaiyah teachers Al-Husna Ciledug including teaching ability, personality skills, professional skills, and social skills, have been outstanding, and very supportive of learning activities in madrassas.

Educators and education personnel expected to master all teacher competencies to be role models for students because all aspects of cognitive, attitude and behaviour are interconnected. In the scope of this guarantee, confidence and sense of security can improve so that customers feel satisfied and loyal to madrasah. This dimension of assurance can increase confidence and security to make customers feel satisfied and loyal to Madrasah. Providing a service that demonstrates a polite and friendly attitude will guarantee comfort for the parents as customers of Islamic education.

\subsection{Empathy Dimension}

The quality of education services in the caring dimension (empathy) is the ability of Madrasah Ibtidaiyah Al-Husna Ciledug in providing services related to the willingness of educators and educational personnel that saw in terms of relationships, communication, understanding, and attention to the needs and complaints of consumers. The form of empathic attitude will make the customer feel fulfilled his needs because he feels well served. Providing information services and customer complaints and service attitudes in the education financing process can help educators and education personnel and help customers when experiencing questions or other matters related to Islamic education services.

Willingness to pay attention and help improve understanding and positive attitude towards organization services. It will bring joy, satisfaction. Moreover, increase customer loyalty. The research results obtained data that the dimension component of care (empathy) consisting of seven indicators obtained an average weight value of 73 with the excellent category. The results showed that the madrassa's empathy saw as good enough in shaping the quality of Islamic education services to the parents as customers of Islamic education. In the dimension of care (empathy) available in Madrasah Ibtidaiyah Al-Husna Ciledug the main indicator that must be immediately corrected is in the 3rd attribute about teachers knowing the wishes and needs of students with a gap value of -0.86 . 
Based on the observation results obtained by a teacher should be able to give attention and care with all students well and understand what the parents and students want as customers of Islamic education. Madrasah is an Islamic educational institution should always pay special attention to each student and student guardian as a customer of Islamic education. It can saw by applying communication patterns that are accompanied by an understanding of all students studying in Madrasah. It is also a form of obedience to God's command to be respectful of others' needs. The above analysis if associated with caring or empathy, then Lovelock (2010) explained that empathy is one form of personal attention to members. Understanding members' needs is an essential factor in influencing members' satisfaction and trust to establish good emotional relationships.

\section{CONCLUSION}

The results of the analysis of the quality of Islamic education customer service in the implementation of Islamic education quality management in Madrasah conducted by researchers using SERVQUAL analysis covering five dimensions namely tangibles, responsivity, reliability, assurance, and empathy with the average result of $71 \%$ customer satisfaction can be fulfilled by Madrasah as a provider of Islamic education services. If the value in each dimension of service quality is still below the number 100, so it can conclude that the service that has implemented has not met the expectations of education customers in Madrasah Ibtidaiyah Al-Husna Ciledug, so it must take action namely: 1) make quality improvements to the dimensions with the highest gap value, 2) prioritize service improvement on attributes with the highest gap value, 3) maintain the quality of service on attributes with low gap value.

\section{ACKNOWLEDGEMENTS}

We would like to thank the board of Al-Husna Rahmat Foundation, the Head of Madrasah, the board of teachers and staff and all the parents. They have been willing to answer the questionnaire given so that this article's research and writing can be completed correctly and on time.

\section{REFERENCES}

Arif, M. (2010) Sketsa Sejarah, Geliat, dan Dinamika Peran Madrasah dalam Merespon Tantangan Pendidika Islam (Dilema Madrasah dalam Kancah Pendidikan dan Peran Kontributif Madrasah Berbasis Pesantren). Eds. Prof. Dr. Nizar Ali, M.Ag dan Dr. H. Sumedi, M.Ag. dalam Ontologi Pendidikan Islam, Program Pascasarjana UIN Sunan Kalijaga kerjasama Penerbit Idea Press: Yogyakarta.

Crosby, B, Philip, (1979) Quality is Free: The Art of Making Quality Certain, McGraw Hill Book Company: New York. 
Efferi, A. (2014). Dinamika Persaingan Antar Lembaga Pendidikan, Jounal of Emperical Islaimc Education, STAIN Kudus, 2 (1).

Erlita, N. (2018). The Website Management of www ppid.dpr.go.id in public information services 2014, American Journal of Humanities and Social Science Research, 2 (11), 20.

Faizal, I. (2012). Dampak Kualitas Pelayanan Jasa Pendidikan Terhadap Kepuasan Peserta Didik pada Jurusan Keselamatan Penerbangan, Jurnal Aviasi Langit Biru: STPI Curug, Vol. 5, No. 11.

Koontz, Horoold, Weihrich, \& Heinz. (2008) Essential of Management an International Perspective, Tata McGraww-Hill Publishing Company Limited: New Delhi.

Kotler, P. (1979), Manajemen Pemasaran, Analisis Perencanaan, Implementasi, dan Kontrol, Hendra Teguh dan Ronny A Rusli (Pentj), PT Pabelan: Bekasi.

Kotler, P. (1979). (2003), Marketing Management, 11 th Edition, Prentice Hall Int'l: New Jersey. Kridhawati, S. (2009). Etika Birokrasi dalam Pelayanan Publik, CV Citra: Malang.

Kritiner, R. (1989). Management, 4 Edition, Houhgton Miffin Company: Boston.

Kumar, A. \& Rachana, S. 2000) Principles Of Busines Management, Atlantics Publisher and Distributors: New Delhi.

Lovelock, C. (2010) Pemasaran Jasa: Manusia, Teknologi, Strategi, Terj Dewi Wulandari dan Devri Bernardi, Erlangga: Jakarta.

Pramana, Y. \& Rastini. (2016). Pengaruh Kualitas Pelayanan Tehadap Kepercayaan Nasabah dan Loyalitas Nasabah Bank Mandiri Cabang Veteran, Denpasar, Bali (online), Vol. 5, No. 1.

Stamatis, D.H. (1996), Total Quality Service, Principles, Practices, and Implementation, CRC Press LLC: Boca Raton, Florida.

Stoner, F.J. (2005). Management Sixt Edition, Prentice Hall: New Jersey.

Sugiyono. (2016). Metode Penelitian Pendidikan Pendekatan Kuantitatif, Kualitatif, dan R \& D, Alfabeta: Bandung.

Sujana, H. D. (2004). Manajemen Program Pendidikan, Falah Production: Bandung.

Sulistyorini. (2005). Manajemen Pendidikan Islam, DIKTAT, STAIN Tulungagung

Tjiptono, F. (2005) Prinsip-Prinsip Total Quality Service, Andi: Yogyakarta.

Umar, H. (2003) Strategik Manajemen in Action, PT Gramedia Pustakama: Jakarta.

Zethalm, A. Parasuraman, \& Berry, L. (1985). A Conceptual Model of Service Quality and its Implication for Future Research, Journal of Marketing, Vol 49, hh. 41-50. 